\title{
Planning Activities and Maintenance Time Intervals of Induction Machines using The Reliability Centered Maintenance (RCM) II and Age Replacement Method
}

\author{
Case Study: CV. Sumber Baja Perkasa
}

Trio Yonathan Teja Kusuma ${ }^{1, *}$ Muhammad Khaedzar Assagaf ${ }^{1}$

Fidia Deny Tisna Amijaya ${ }^{1}$

${ }^{1}$ Industrial Engineering Department, Faculty of Science and Technology, Universitas Islam Negeri Sunan Kalijaga,
Yogyakarta, Indonesia
${ }^{*}$ Corresponding author. Email: trio.yonathan@gmail.com

\begin{abstract}
CV. Sumber Baja Perkasa is a company engaged in manufacturing metal smelting and printing which can produce various metal products such as pulleys and brake wheels. In this study, the object studied is an induction machine which often experiences damage during the production process. Damage that occurs can interfere with the production process so that the production target is not achieved. In addition, the maintenance actions that have been implemented so far by the company are in the form of corrective maintenance or limited to cleaning and replacement when damage occurs, but still damage to induction machines is still common. Based on the problems that occur, the right treatment method is needed, one of which is by applying preventive maintenance actions through the RCM II decision worksheet and Age Replacement methods. The purpose of applying these two methods is to determine the appropriate maintenance activity policy and to obtain optimal component replacement maintenance intervals so as to reduce maintenance costs. From the research results, it is known that the types of maintenance activities and replacement time intervals are sequential, namely for the SCR component, the type of activity applied is a scheduled combination of task (scheduled on conditional task and scheduled discard task) with a time interval of 294 hours, for components of niklin wire and anaconda cable. the type of activity implemented is scheduled discard task with time intervals of 451 hours and 397 hours, for the clamping component the type of activity applied is scheduled restoration task with time interval of 617 hours. each component of the induction machine by $22 \%, 28 \%, 25 \%$ and $24 \%$.
\end{abstract}

Keywords: Maintenance, Preventive Maintenance, Corrective Maintenance, RCC II Decision worksheet and Age Replacement.

\section{INTRODUCTION}

The achievement of a company's production target is determined by the smoothness of the production process itself. The smooth production process is determined by the existence of a good production system where one of the constituent components is the machine unit used. Every production process takes place requires a readiness and reliability of a machine unit that is used to operate optimally every time. However, machines that are used continuously may result in machines prone to breakdown and cause losses. This can be done by implementing a management system in the form of preventive maintenance actions that are planned, carried out and carried out properly in order to obtain more effective maintenance activities. 
CV. Sumber Baja Perkasa is a company engaged in manufacturing metal smelting and molding which is located at Ceper, Klaten District, Central Java. The main machine used in production activities is an induction machine which functions to melt metals. Based on company record data, component damage that occurs in induction machines is usually caused by vital components of the machine that fail to function so that the machine turns off and cannot operate optimally. The condition of the damaged machine will certainly affect the course of the production process so that the production target is not achieved. So far, the maintenance action implemented in the company is in the form of corrective maintenance where repairs, inspections and component replacements are carried out unplanned and carried out when damage occurs.

Based on historical damage data for January 2017December 2018 it is known that the machine has broken down 34 times with a total downtime of 143 hours in 3024 hours of production time. So that the large loss due to the induction machine downtime when exemplified in one of the brakewhell products is Rp. 87,340,500. The solution that can be applied to companies in determining maintenance activity policies and planning maintenance times in order to reduce maintenance costs is the preventive maintenance approach through the RCMII and Age Replacement methods.

The RCM II method is an integrated method of quantitative and qualitative analysis in determining engine maintenance planning where RCM II has the advantage of determining a maintenance plan that is focused on critical machines and avoiding unnecessary maintenance activities [1]. While the Age Replacement method is a preventive replacement model that depends on the life of the component. Preventive replacement is carried out by setting the next material preventive time interval, according to a predetermined time interval in the event of damage that requires replacement action (Jardine, 1973). In this study, the RCM II method is used to determine the appropriate maintenance activity policy to be applied, while the determination of component replacement maintenance time can be done through Age Replacement.

This can be proven by looking at the research conducted by Yulianti and Adinata (2016), with the title of scheduling component replacement on rolling and heading machines at PT. DRA Component Persada with the Age Replacement method, the result is that the optimum replacement time interval for punch components is 140 hours, pin guides are 150 hours, and rolling dies are 220 hours, besides that, maintenance costs savings on the three components are $70 \%, 71,92 \%$ and $60.14 \%$.

This study only examines machine maintenance, with the aim of the study being to determine the appropriate maintenance activity policy and determine the optimal maintenance time interval in order to reduce machine maintenance costs. It is hoped that this research will be able to assist the company in making the right decision so that it can reduce the cost of maintenance carried out on the induction machine.

\section{RESEARCH METHODS}

In this study, the data analysis method used consisted of several stages. The research phase starts from reviewing literature studies and observing field studies, identifying problems, collecting data, processing data I, identifying distributions, processing data II, determining the results of analysis and discussion, making conclusions and suggestions. The stages of the research can be seen in Figure 1

\subsection{Data Collection Stage}

In helping to collect data, there are several data collection techniques used, namely as follows:

\section{Literature Study}

Literature study is used as reference material in supporting knowledge related to the theme used.

\section{Observation}

Observations are made directly in the field, to find out objects and things related to research.

\section{Interview}

Interview is a method of asking a number of questions to the competent and competent parties to support the required data.

\section{Document study}

Document study is documentation data from the company in the form of recording data such as bookkeeping and soft files.

\subsection{Data Processing Stage}

At this data processing stage, it can be done by classifying data processing according to qualitative and quantitative data. The stages of processing qualitative and quantitative data can be seen as follows:

\section{Qualitative data processing}

Qualitative data processing is carried out using the Failure Mode and Effects Analysis (FMEA) method and the RCM II Decision Worksheet. The FMEA and RCM II Decision Worksheet stages are as follows :

- Identification of components and functions

- Identification of potential failure mode

- Identification of potential effect failure

- Identification of cause of failure

- Identification of current control 
- Assessment of Severity

- Assessment of Occurrence

- Assessment of Detection

- Pareto Diagram

- Calculation of component values critical care and determination of care policy with RCM II decision worksheet.
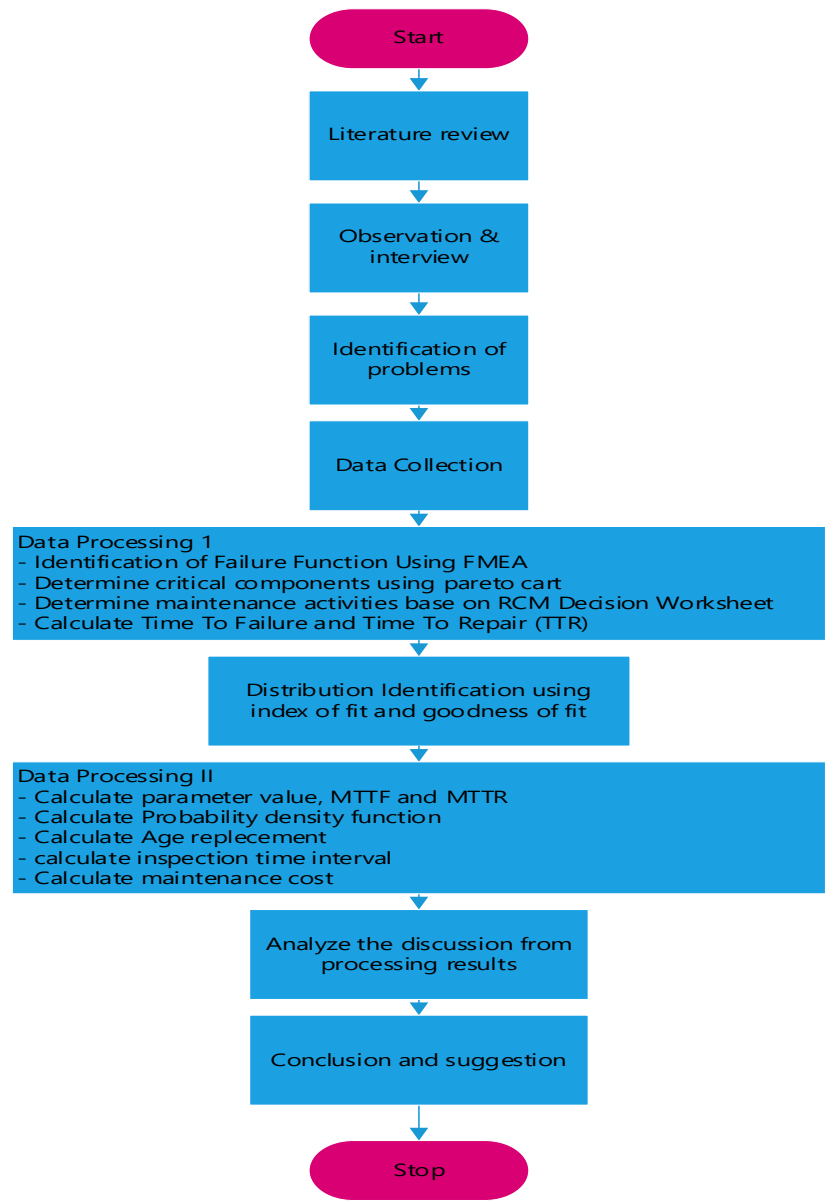

Figure 1 Research Flowchart

2. Quantitative data processing

Quantitative data processing is carried out based on time data between component failure and repair. The stages of quantitative data processing are as follows:

a. Calculation of the time interval between damage (TTF) and repair (TTR)

- $\quad$ Time to Repair (TTR)

The range of time from the start of the damage to the time of completion of the damage

- $\quad$ Time to Failure (TTF)

((Time of completion of damage - hours of work - completed $)+($ Hours of work start broken start time $)+($ Business hours $)$ ) . b. Identification Of The Distribution Of Time Lapse Between Damage (TTF) And Repair (TTR)

c. Calculation Of Parameters Of Time Lapse Between Damage (TTF) And Repair (TTR)

- $\quad$ Normal Ditribution $(\sigma$ and $\mu)$

- Lognormal Distribution

d. MTTF and MTTR Calculation

- MTTF $_{\text {Normal }}=\mu$

- $\quad \mathrm{MTTR}_{\text {Lognormal }}=\mathrm{t}_{\mathrm{med}} e^{\frac{s^{2}}{2}}$

e. Find the Probability Destiny Function

- $f(\mathrm{t})=\frac{1}{\sigma \sqrt{2 \pi}} e^{\left.\left[-\frac{1}{2}\left(\frac{t-\mu}{\sigma}\right)^{2}\right)\right]}$, for $-\infty \leq \mathrm{t} \leq \infty$

f. Determine Preventive Replacement

- $\mathrm{F}(\mathrm{tp})=\Phi\left(\frac{\mathrm{tp}-\mu}{\sigma}\right)$

- $\mathrm{R}(\mathrm{tp})=1-\mathrm{F}(\mathrm{tp})$

- $\mathrm{M}(\mathrm{tp})=\frac{\mathrm{MTTF}}{F(t p)}$

- $\quad \mathrm{D}(\mathrm{tp})=\frac{\mathrm{Tp} * \mathrm{R}(\mathrm{tp})+\mathrm{Tf}(1-\mathrm{R}(\mathrm{tp}))}{(t p+T p) * R(t p)+(M(t p))+T f) *(1-R(t p))}$

- $\quad \mathrm{A}(\mathrm{tp})=1-\mathrm{D}(\mathrm{tp})$

g. Determine the Optimal Inspection Time of Components

- Average working hours

- Total damage over time

- $\quad$ Average demage $(\mathrm{k})$

$$
\mathrm{k}=\frac{\text { Amount of Damage Over Time }}{\text { Time Period }}
$$

- Average time it takes to do $\operatorname{repair}(\mu)$

$$
\begin{aligned}
& 1 / \mu=\frac{M T T R}{\text { Working hours every } 1 \text { month }} \\
& \mu=\frac{1}{1 / \mu}
\end{aligned}
$$

- $\quad$ average examination time (i)

$$
\begin{aligned}
1 / \mathrm{i} & =\frac{\text { Average } 1 x \text { Time Check }(t i)}{\text { Working hours every } 1 \text { month }(t)} \\
\mathrm{i} & =\frac{1}{1 / \mathrm{i}}
\end{aligned}
$$

- Calculation of examination frequency (n) and Interval time (ti)

$$
\begin{aligned}
& \mathrm{n}=\sqrt{\frac{k x i}{\mu}} \& \mathrm{ti}= \\
& \frac{\text { Working hours every } 1 \text { month }(t)}{n}
\end{aligned}
$$

- $\quad$ Downtime Value Calculation (D)

$$
\mathrm{D}(\mathrm{n})=\frac{k}{n x \mu}+\frac{n}{i}
$$


- Availability calculation (A)

$$
\mathrm{A}(\mathrm{tp})=1-\mathrm{D}(\mathrm{tp})
$$

h. Determination of preventive and corrective costs

- Determination of cycle costs for failure (Cf) and preventive $(\mathrm{Cp})$

$\mathrm{Cf}=$ Cost of components $+(($ Cost of Technician + Cost of production loss) $\mathrm{x}$ Tf.

$\mathrm{Cp}=$ Cost of component $+(($ Cost of Technician + Cost of production loss) $\mathrm{x}$ Tp.

\section{RESULTS AND DISCUSSION}

\subsection{Machine Damage Time Data}

Research is focused on induction machines because this machine is the main machine and is often damaged. The time data for damage is from January 2017 December 2018.

\section{2..Failure Mode and Effect Analysis (FMEA)}

FMEA is performed to determine the failure rate based on the RPN value, while the RPN value is the result of multiplying the three FMEA criteria, namely severity, occurrence and detection. Meanwhile, based on the RPN ranking, the highest damage is found in the SCR component with an RPN of 168.

\subsection{Determination of Critical Components}

In determining the critical components of an induction machine, it can be done using a Pareto diagram by sorting the total RPN starting from the largest to the smallest value. As for making the Pareto diagram, it follows the Pareto 80:20 principle. It is known that according to Figure 2, where the components included in the $80 \%$ category there are 6 components, namely: SCR components, anaconda cable components, niklin wire components, clamp components, capacitor components and motherboard components.

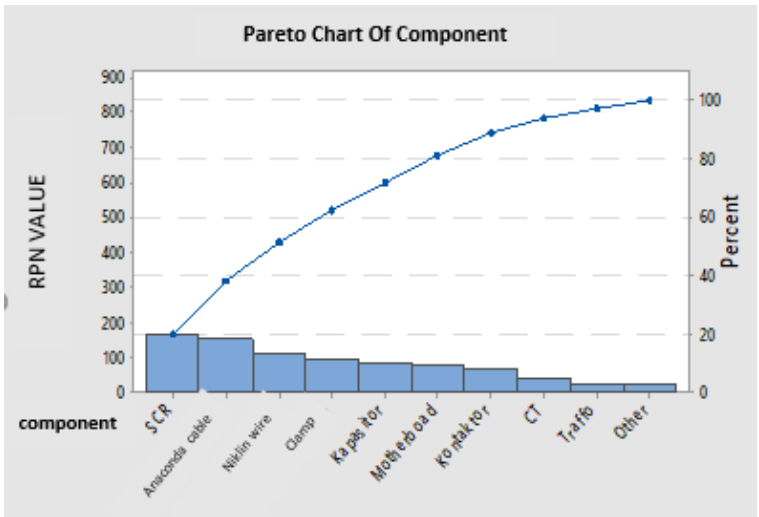

Figure 2 Pareto Diagram

\subsection{RCM II Decision Worksheet.}

RCM II decision worksheet is a method used to find the right type of maintenance activity (Maintenance Task) and has the possibility to overcome every failure mode that occurs. Meanwhile, in helping to determine the appropriate assessment and type of maintenance activity against failure mode, it comes from questions on the RCM decision diagram sourced [1]. Based on the analysis of determining the policy of maintenance activities on the 6 critical components, it is known that for the SCR and capacitor components maintenance action is carried out in the form of a scheduled combination of task, for the niklin wire, anaconda cable and motherboard components, maintenance action is carried out in the form of scheduled discard task, for the clamp component, action is taken in the form of a scheduled restoration task. The determination of the type of maintenance activities obtained is contained in the attachment sheet.

\subsection{Calculation of Time between Damage (TTF) and Repair (TTR).}

The TTF and TTR values after being calculated and sorted according to the value can be seen on Table 1 .

\subsection{Identification of the Distribution of Time Lapse Between Damage (TTF)}

Based on the data on the time lapse between damage (TTF) and repair (TTR), the goodness of fit test was then used using the minitab ver.17 application. The goodness of fit test is used to assist in determining the selected distribution according to the correlation coefficient and Anderson Darling. The distribution of the four components is known on Table 2.

\subsection{Determining the Parameter Value of TTF and TTR}

Data Based on the results of the goodness of fit test where the distribution selected for each component is used in determining the parameter values to determine MTTF and MTTR, they are on Table 4.

\subsection{Opportunity Density Function}

In determining the probability of damage when the machine reaches the maximum damage limit, it can be known by calculating the probability density function.

Based on Table 6, the results of the calculation of the probability-intensive function, the probability of damage to the induction machine will reach the maximum damage when it reaches a value of 0.004296287 or occurs at the 319 hour interval for the SCR component. While the other components according to Table 6 . 
Table 1. TTF and TTR values for SCR components.

\begin{tabular}{|c|c|c|}
\hline No. & $\begin{array}{c}\text { Repair } \\
\text { Time } \\
\text { (hours) }\end{array}$ & $\begin{array}{c}\text { Breakdown } \\
\text { Time } \\
\text { (hours) }\end{array}$ \\
\hline 1 & 3,10 & 186,61 \\
\hline 2 & 3,11 & 226,61 \\
\hline 3 & 3,14 & 233,41 \\
\hline 4 & 3,20 & 298,42 \\
\hline 5 & 3,23 & 311,05 \\
\hline 6 & 3,35 & 338,50 \\
\hline 7 & 3,40 & 395,02 \\
\hline 8 & 3,51 & 427,85 \\
\hline 9 & 4,06 & 449,89 \\
\hline 10 & 4,17 & \\
\hline
\end{tabular}

Table 2. Selected Distribution of TTF Data

\begin{tabular}{|c|c|c|c|}
\hline Component & $\begin{array}{c}\text { Correlation } \\
\text { Coefficient }\end{array}$ & $\begin{array}{c}\text { Anderson } \\
\text { Darling }\end{array}$ & $\begin{array}{c}\text { Selected } \\
\text { Distribution }\end{array}$ \\
\hline SCR & 0,9850 & 1,4580 & Normal \\
\hline Niklin wire & 0,9558 & 2,1130 & Lognormal \\
\hline $\begin{array}{c}\text { Anaconda } \\
\text { cable }\end{array}$ & 0,9984 & 2,7750 & Normal \\
\hline Clamp & 0,9804 & 2,8150 & Weibull \\
\hline
\end{tabular}

Table 3. Selected distribution of TTF data

\begin{tabular}{|c|c|c|c|}
\hline Component & $\begin{array}{c}\text { Correlation } \\
\text { Coefficient }\end{array}$ & $\begin{array}{c}\text { Anderson } \\
\text { Darling }\end{array}$ & $\begin{array}{c}\text { Selected } \\
\text { Distribution }\end{array}$ \\
\hline SCR & 0,91009 & 1,8820 & Lognormal \\
\hline Niklin wire & 0,96442 & 1,9800 & Weibull \\
\hline $\begin{array}{c}\text { Anaconda } \\
\text { cable }\end{array}$ & 0,96684 & 2,3660 & Normal \\
\hline Clamp & 0,91621 & 2,6070 & Weibull \\
\hline
\end{tabular}

Table 4. Distribution parameter Values and MTTF

\begin{tabular}{|c|c|c|c|}
\hline Component & $\begin{array}{c}\text { TTF } \\
\text { Distribution }\end{array}$ & Parameter & $\begin{array}{c}\text { MTTF } \\
\text { (hours) }\end{array}$ \\
\hline \multirow{2}{*}{ SCR } & \multirow{2}{*}{ Normal } & $\begin{array}{c}\mu \\
=318,5956\end{array}$ & \multirow{2}{*}{318,5956,} \\
\cline { 3 - 3 } & & $\begin{array}{c}\sigma= \\
92,88013\end{array}$ & \\
\hline \multirow{3}{*}{ Niklin wire } & Lognormal & $\begin{array}{c}\mathrm{s}= \\
0,2690197\end{array}$ & \multirow{2}{*}{$5,012,999$} \\
\cline { 3 - 3 } & & $\begin{array}{c}\text { tmed }= \\
483,484\end{array}$ & \\
\hline
\end{tabular}

\begin{tabular}{|c|c|c|c|}
\hline \multirow{2}{*}{$\begin{array}{c}\text { Anaconda } \\
\text { cable }\end{array}$} & \multirow{2}{*}{ Normal } & $\begin{array}{c}\mu= \\
443,7075\end{array}$ & \multirow{2}{*}{443,707} \\
\cline { 3 - 3 } & & $\begin{array}{c}\sigma= \\
179,96116\end{array}$ & \\
\hline \multirow{2}{*}{ clamp } & \multirow{2}{*}{ Weibull } & $\theta=3,41708$ & \multirow{2}{*}{$6,761,188$} \\
\cline { 3 - 3 } & & $\begin{array}{c}\beta= \\
752,045\end{array}$ & \\
\hline
\end{tabular}

Table 5. Distribution parameter values dan MTTF

\begin{tabular}{|c|c|c|c|}
\hline & $\begin{array}{c}\text { TTR } \\
\text { Distrib- } \\
\text { ution } \\
\end{array}$ & Parameter & $\begin{array}{l}\text { MTTR } \\
\text { (hours) }\end{array}$ \\
\hline \multirow{2}{*}{ SCR } & \multirow[b]{2}{*}{ normal } & $\begin{array}{c}\mathrm{s}= \\
0,10170089\end{array}$ & \multirow{2}{*}{3,426378} \\
\hline & & $\begin{array}{l}\text { tmed } \\
=3,408705\end{array}$ & \\
\hline \multirow{2}{*}{ Niklin wire } & \multirow{2}{*}{ Weibull } & $\begin{array}{c}\theta= \\
3,588343\end{array}$ & \multirow{2}{*}{3,348067} \\
\hline & & $\begin{array}{c}\beta= \\
6,737057 \\
\end{array}$ & \\
\hline \multirow{2}{*}{$\begin{array}{l}\text { Anaconda } \\
\text { cable }\end{array}$} & \multirow[b]{2}{*}{ Normal } & $\mu=4,636$ & \multirow[b]{2}{*}{4,63600} \\
\hline & & $\begin{array}{c}\sigma= \\
0,54720197\end{array}$ & \\
\hline \multirow{2}{*}{ Clamp } & \multirow{2}{*}{ Weibull } & $\begin{array}{c}\theta= \\
4,477630\end{array}$ & \multirow{2}{*}{4,06802} \\
\hline & & $\begin{array}{c}\beta= \\
4,21536\end{array}$ & \\
\hline
\end{tabular}

Table 6. Critical component probability density function

\begin{tabular}{|c|c|c|}
\hline No. & Component & Time Interval \\
\hline 1 & SCR & 319 hour \\
\hline 2 & Niklin wire & 479 hour \\
\hline 3 & Anaconda cable & 444 hour \\
\hline 4 & Clamp & 680 hour \\
\hline
\end{tabular}

$f(t) \quad=\frac{1}{\sigma \sqrt{2 \pi}} e^{\left.\left[-\frac{1}{2}\left(\frac{t-\mu}{\sigma}\right)^{2}\right)\right]}$, to $-\infty \leq t \leq \infty$

$f(319)=0,004296287$

probability-intensive function $(F(t p))$

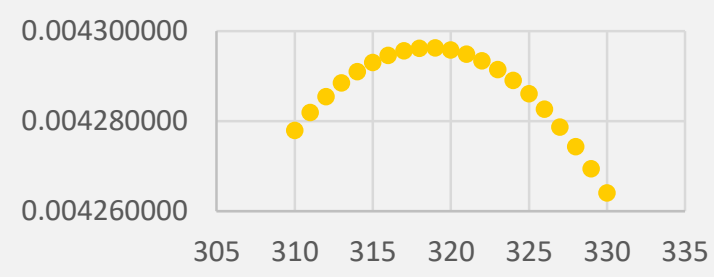

Figure 3 Grafik of the probability-intensive function 


\subsection{Age Replacement}

Table 7. Preventive critical component replacement time interval

\begin{tabular}{|c|c|c|}
\hline No. & Component & $\begin{array}{c}\text { Preventive } \\
\text { Replacement } \\
\text { Time } \\
\text { Interval }\end{array}$ \\
\hline 1 & SCR & 294 hour \\
\hline 2 & Niklin wire & 451 hour \\
\hline 3 & $\begin{array}{c}\text { Anaconda } \\
\text { cable }\end{array}$ & 397 hour \\
\hline 4 & Clamp & 617 hour \\
\hline
\end{tabular}

Based on Table 7, it is known that the level of reliability of the components is determined based on the reference table for depreciation of production and transportation machines based on international standards, where the minimum reliability limit is $60 \%$ of the initial reliability limit of the machine so that for the SCR component the reliability function value is 0.6026 or 60.3 $\%$ when it reaches the 294th hour. While the other components are according to Table 7 .

Table 8. Age replacement

\begin{tabular}{|c|c|c|c|c|c|}
\hline Interval & & $\Phi$ F(tp) & & & \\
\hline $\begin{array}{c}\text { tp } \\
\text { (hour) }\end{array}$ & $\boldsymbol{\mu}) / \boldsymbol{\sigma}$ & (kumulatif) & $\mathbf{R}(\mathbf{t p})$ & $\mathbf{M}(\mathbf{t p})$ & $\mathbf{D}(\mathbf{t p})$ \\
\hline 290 & $-0,308$ & 0,3783 & 0,6217 & 842,22 & 0,00568 \\
\hline 291 & $-0,297$ & 0,3821 & 0,6179 & 833,83 & 0,0057 \\
\hline 292 & $-0,286$ & 0,3859 & 0,6141 & 825,57 & 0,00571 \\
\hline 293 & $-0,276$ & 0,3897 & 0,6103 & 817,46 & 0,00572 \\
\hline 294 & $-0,265$ & 0,3974 & 0,6026 & 801,64 & 0,00576 \\
\hline 295 & $-0,254$ & 0,4013 & 0,5987 & 793,92 & 0,00577 \\
\hline 296 & $-0,243$ & 0,4052 & 0,5948 & 786,34 & 0,00578 \\
\hline 297 & $-0,233$ & 0,409 & 0,591 & 778,87 & 0,0058 \\
\hline 298 & $-0,222$ & 0,4129 & 0,5871 & 771,54 & 0,00581 \\
\hline 299 & $-0,211$ & 0,4168 & 0,5832 & 764,32 & 0,00582 \\
\hline
\end{tabular}

\subsection{Optimal Inspection Time of Components}

The value of the inspection time interval of each component obtained is as follows on Table 9.

Table 9. Value of critical component inspection time

\begin{tabular}{|c|c|c|}
\hline No. & Component & $\begin{array}{c}\text { Inspection Interval Time } \\
\text { (hours) }\end{array}$ \\
\hline 1 & SCR & 141,45317 \\
\hline 2 & Niklin wire & 171,03469 \\
\hline 3 & Anaconda cable & 198,58342 \\
\hline 4 & Clamp & 105,99695 \\
\hline
\end{tabular}

Inspection time interval 141,453167 or every 13 days production.

\subsection{Determination of Preventive and Corrective Maintenance Costs}

Maintenance costs based on preventive and corrective maintenance actions can be identified as follows:

1. Determining Labor Costs

Labor costs (technicians) are costs incurred for workers who perform maintenance actions.

2. Determine the cost of purchase

The cost of purchasing components, namely the costs incurred due to damage that requires component replacement.

3. Determine the cost of loss or production loss

Production loss costs are costs that arise as a result of downtime, causing loss of production or called Opportunity costs due to the company not being able to produce goods because the machine is experiencing downtime.

Cost of Corrective Maintenance

$$
\begin{aligned}
\mathrm{Kf} \quad & \frac{\text { total product defacts }}{\text { Total month }}=\frac{10}{24} \\
=0,416667 & \\
\mathrm{TC}(\mathrm{tp}) & =\mathrm{Cf} \times \mathrm{Kf} \\
& =\mathrm{Rp} \cdot \mathrm{Rp} \cdot 24.018 .703,84 . \times 0,416667 \\
& =\text { Rp. } 10.007 .793,27 / \text { month }
\end{aligned}
$$

Cost of Preventive Maintenance

Age Replacement $(\mathrm{T})=294$ hour

$\mathrm{Cp} \quad=$ Rp. 17.953 .720

$\mathrm{R}(\mathrm{tp}) \quad=0,60642$

$\mathrm{M}(\mathrm{tp})=801,64$

$\mathrm{TC}(\mathrm{tp})=\frac{(17.953 .720 \times 0,60642)+(24.018 .703,84(1-0,60642))}{(0,60642)+((801,64 \times(1-0,60642))}$

$=$ Rp.7.815.230,734

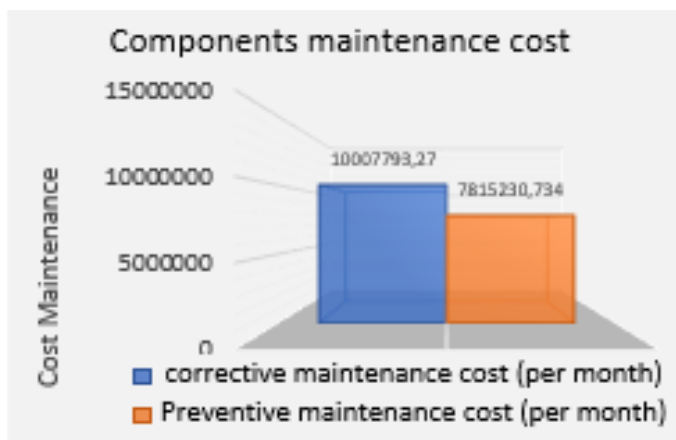

Figure 4 Comparison of SCR component maintenance costs 
Table 10. Comparative values of corrective and preventive maintenance costs

\begin{tabular}{|c|c|c|c|c|}
\hline $\begin{array}{l}\text { Compo- } \\
\text { nent }\end{array}$ & $\begin{array}{l}\text { Correctiv } \\
\text { Mainte- } \\
\text { nance } \\
\text { Cost }\end{array}$ & $\begin{array}{l}\text { Preventiv } \\
\text { Mainte- } \\
\text { nance } \\
\text { cost }\end{array}$ & Cost saving & Percent (\%) \\
\hline SCR & $\begin{array}{l}10.007 . \\
793,27\end{array}$ & $\begin{array}{l}7.815 . \\
230,73\end{array}$ & $\begin{array}{l}2.192 . \\
562,53\end{array}$ & 22 \\
\hline $\begin{array}{c}\text { Niklin } \\
\text { wire }\end{array}$ & 6.415. & 4.632. & 1.783. & 28 \\
\hline $\begin{array}{c}\text { Anaconda } \\
\text { cable }\end{array}$ & 787,23 & 209,20 & 578,04 & 25. \\
\hline Clamp & 5.550. & 5.267. & 1.765. & 25 \\
\hline
\end{tabular}

\section{CONCLUSION}

Based on the analysis results of the RCM II discussion, the decision worksheet to be given the right maintenance policy is for components of niklin wire, anaconda cable and motherboard with the type of damage is broken niklin wire, busbar (brass copper) is broken, and the power supply is dead is to provide maintenance activities in the form of scheduled discard task, then for SCR components and capacitors with the type of damage is the surface of the SCR is charred or burned and the current cable from the transformer is burned is to provide maintenance activities in the form of scheduled combination of task (scheduled on conditional task and scheduled discard task). Meanwhile, for clamping components with rusty or dirty type of clamp ring damage, it is to provide maintenance activities in the form of scheduled restoration tasks.

Based on the results of the analysis of the discussion, the optimal preventive replacement time interval is obtained in order to obtain cost savings. As for each component, the optimal preventive replacement time interval and cost savings sequentially are obtained, namely SCR at 294 hours with cost savings of Rp. $2,192,562,532$ or $22 \%$, niklin wire at 451 hours with a cost savings of Rp. $1,783,578.036$ or $28 \%$, anaconda cable on the 397th hour with a cost savings of Rp. $1,765,690,322$ or $25 \%$ and clamp on the 617 th hour with cost savings of Rp. $1,349,056,441$ or $24 \%$.

\section{REFERENCES}

[1] Moubray, J. 1997. Reliability Centered Maintenance 2nd Edition. New York : Industrial Press Inc. Madison Avenue.

[2] Jardine, Andrew KS, and Tsang, AHC, "Maintenance, replacement, and reliability: theory and applications", CRC press, 2006.
[3] Ebeling, C, "An Introduction to Reliability and Maintainability Engineering”, McGraw Hill, 2003.

[4] Fata, "Analisis Reliability Centered Maintenance dan Maintenance Value Stream Map", Skripsi, Universitas Islam Negeri Sunan Kalijaga, 2017.

[5] Fischer, K. et al, "A Limited Scope Reliability Centered Maintenance Analysis of Wind Turbines', Sweden, 2011.

[6] Gaspersz, V., "Continuous Cost Reduction Through Lean-Sigma Approach”, PT. Gramedia Pustaka Utama, 2006.

[7] Kurniawan, F., "Manajemen Perawatan Industri Teknik dan Aplikasi Implementasi Total Productive Maintenance (TPM), Preventive Maintenance dan Reliability Centered Maintenance (RCM)", Graha Ilmu, 2013.

[8] Hidayat, R. et al, "Perencanaan Kegiatan Maintenance dengan Metode Reliability Centered Maintenance II", Makara Journal of Technology, 14(1), pp 7-14, Universitas Trunojoyo, 2010.

[9] Montgomery, Douglas C. dan Runger, George C. 2002. Applied Statistics and Probability for Engineers.New York: Permissions department. John Wiley \& Sons, Inc.

[10] Naik, B. Devaraj dan Soni, Pradeep Kumar. 2016. "Application of Reliability Centered Maintenance on Horizontal Boring Machine-A Case Study".International Journal of Advanced Engineering Research and Science(IJAERS). Vol. 3. Issue 7, ISSN:2349-6495. Madhya Pradesh.

[11] Narnaware, Vivek S. et al. 2014. Implementation of Reliability Centered Maintenance in Air Compressor Unit.International journal of mechanical engineering and technology (IJMET). Vol. 5. Issue 1. ISSN 0976-6359.Nagpur.

[12] Purnama, Jaka.et al. 2015. Metode Age Replacement Digunakan untuk Menentukan Interval Waktu Perawatan Mesin Pada Armada Bus.Surabaya:Institut Teknologi Adhi Tama.

[13] Ramadhan, M. A. Z., 2018. Penentuan Interval Waktu Preventive Maintenance Pada Nail Making Machine Dengan Menggunakan Metode Reliability Centered Maintenance (RCM) II . Sidoarjo: Skripsi Teknik Industri. Universitas Muhammadiyah Sidoarjo.

[14] Sari, Dian Puspita dan Ridho. 2016."Evaluasi Manajemen Perawatan Dengan Metode Reliability Centered Maintenance (RCM) II Pada Mesin Blowing I di Plant I PT. Pisma Putra Textile".Hal 73-80.Semarang.: Universitas Diponegoro. 
[15] Sefurrokhim, David. 2013. Penjadwalan Perawatan Preventive Komponen Kritis Pada Mesin Excavator Studi Kasus PT. Putra Batu Mulia Kalimantan.Yogyakarta: Skripsi Teknik Industri. Universitas Islam Negeri.

[16] Sembiring, N. et al. 2017. The Engine Maintenance Scheduling by Using Reliability Centered Maintenance Method and The Identification of 5S Application in PT.XYZ.Medan: Universitas Sumatera Utara.

[17] Sumantri, Ade H. 2013. Analisis RPN terhadap Keandalan Instrumentasi Kompresor Udara Menggunakan Metode FMEA di PT. Pertamina (PERSERO) Refinery Unit II Dumai.Riau: Skripsi Teknik Elektro. Universitas Islam Negeri Sultan Syarif Kasim.

[18] Taufik dan Septyani. 2015. Penentuan Interval Waktu Perawatan Komponen Krits Pada Mesin Turbin di PT. PLN (PERSERO) Sektor Pembangkit Ombilin.ISSN 2088-4842. Padang: Universitas Andalas.
[19] Vidiasari, Defri. et al.2015. "Interval Waktu Penggantian Penncegahan Optimal Komponen Sistem Printing Unit U41 Menggunakan Metode Age Replacement di PT.Pikiran Rakyat”. Jurnal online Institut Teknologi Nasional. Vol. 03. No. 01, ISSN: 2338-5081.Bandung: Institut Teknologi Nasional.

[20] Widyaningsih, Sri. A. 2011. Perancangan Penjadwalan Pemeliharaan Pada Mesin Produksi Bahan Bangunan Untuk Meningkatkan Kehandalan Mesin Dengan Metode Reliability Centered Maintenance. Depok: Skripsi Teknik Industri. Universitas Indonesia.

[21] Yulianti, Nur dan Adinata, M. Zhona. 2018. Penjadwalan Penggantian Komponen Pada Mesin Rolling dan Heading di PT. DRA Component Persada dengan Metode

[22] Bangun, I. et al, "Perancangan Pemeliharaan Mesin Produksi Dengan Menggunakan Metode Reliability Centered Maintenance (RCM) II Pada Mesin Blowing Om”, Universitas Brawijaya, 2014. 